\title{
Controllable Synthesis of 2D Perovskite on Different Substrates and Its Application as Photodetector
}

\author{
Yunzhou Xue ${ }^{1}$, Jian Yuan ${ }^{2}$, Jingying Liu ${ }^{3}$ and Shaojuan $\mathrm{Li}^{2, *}$ (i) \\ 1 College of Chemistry and Environmental Engineering, Shenzhen University, Shenzhen 518000, China; \\ xueyz@iccas.ac.cn \\ 2 Collaborative Innovation Center of Suzhou Nano Science and Technology, Jiangsu Key Laboratory for \\ Carbon-Based Functional Materials and Devices, Institute of Functional Nano and Soft \\ Materials (FUNSOM), Soochow University, Suzhou 215123, China; jianyuan_cq@126.com \\ 3 Department of Materials Science and Engineering, Monash University, Clayton, VIC 3800, Australia; \\ jingying.liu@monash.edu \\ * Correspondence: sjli@suda.edu.cn; Tel.: +86-0512-6588-2337
}

Received: 14 June 2018; Accepted: 12 July 2018; Published: 3 August 2018

\begin{abstract}
Perovskites have recently attracted intense interests for optoelectronic devices application due to their excellent photovoltaic and photoelectric properties. The performance of perovskite-based devices highly depends on the perovskite material properties. However, the widely used spin-coating method can only prepare polycrystalline perovskite and physical vapor deposition (PVD) method requires a higher melting point $\left(>350^{\circ} \mathrm{C}\right)$ substrate due to the high growth temperature, which is not suitable for low melting point substrates, especially for flexible substrates. Here, we present the controlled synthesis of high quality two-dimensional (2D) perovskite platelets on random substrates, including $\mathrm{SiO}_{2} / \mathrm{Si}$, $\mathrm{Si}$, mica, glass and flexible polydimethylsiloxane (PDMS) substrates, and our method is applicable to any substrate as long as its melting point is higher than $100{ }^{\circ} \mathrm{C}$. We found that the photoluminescence (PL) characteristics of perovskite depend strongly on the platelets thickness, namely, thicker perovskite platelet has higher PL wavelength and stronger intensity, and thinner perovskite exhibits opposite results. Moreover, photodetectors based on the as-produced perovskite platelets show excellent photoelectric performance with a high photoresponsivity of $8.3 \mathrm{~A} \cdot \mathrm{W}^{-1}$, a high on/off ratio of $\sim 10^{3}$, and a small rise and decay time of 30 and $50 \mathrm{~ms}$, respectively. Our approach in this work provides a feasible way for making 2D perovskite platelets for wide optoelectronic applications.
\end{abstract}

Keywords: 2D perovskite; controllable synthesis; flexible substrate; photodetector; photoelectric performance

\section{Introduction}

Organic-inorganic halide perovskite are materials described by $\mathrm{AMX}_{3}$ formula, in which $\mathrm{A}$ is organic cation, $\mathrm{M}$ is metal cation and $\mathrm{X}$ is halogen anion [1]. Although perovskites have been discovered for more than one century, the use of perovskites in solar cells only happened in recent years [2-10]. Among the variety kinds of perovskites, methylammonium lead iodide perovskite $\left(\mathrm{CH}_{3} \mathrm{NH}_{3} \mathrm{PbI}_{3}\right)$ has attracted intensive interest due to its extraordinary optoelectronic properties such as long electron/hole diffusion lengths, high optical absorption coefficient, and optimal bandgap [11,12]. These advantages have generated widely growing interest for diverse applications such as photodetectors [13-16], light-emitting diodes (LEDs) [17-21], waveguides [22], field effect transistors (FET) [23], lasers [24,25], etc. These applications requires high performance devices which highly depends on the perovskite material properties. To date, there are several methods to prepare $\mathrm{CH}_{3} \mathrm{NH}_{3} \mathrm{PbI}_{3}$ perovskite. Directly spin-coating perovskite compound solution to prepare perovskite films is the simplest method, which 
is suitable for use in solar cells with perovskite as the light harvester $[18,20]$. However, the material properties obtained by this method still cannot fully display the nature of perovskite, due to its inhomogeneous, polycrystalline structure and large surface roughness. Homogeneous and high crystalline perovskite film can be obtained by thermal evaporation, but this method needs dedicated equipment and can easily cause lead poisoning as the lead iodide $\left(\mathrm{PbI}_{2}\right)$ vapor cannot be avoided in the experiment process $[8,26]$. Chemical vapor deposition (CVD) is promising for the synthesis of high quality perovskite with well-defined structures and morphologies $[27,28]$, especially for two-dimensional (2D) $\mathrm{CH}_{3} \mathrm{NH}_{3} \mathrm{PbI}_{3}$ perovskite platelets. This method involves two steps: firstly, $\mathrm{PbI}_{2}$ platelets were grown on mica substrate under $350-510{ }^{\circ} \mathrm{C}$, and then the as-grown $\mathrm{PbI}_{2}$ platelets were converted to $\mathrm{CH}_{3} \mathrm{NH}_{3} \mathrm{PbI}_{3}$ perovskites through inserting the $\mathrm{CH}_{3} \mathrm{NH}_{3} \mathrm{I}$ molecules into the $\mathrm{PbI}_{2}$ platelets under $120^{\circ} \mathrm{C}$ [29]. Although high quality perovskite can be obtained by this method, it would still induce lead poisoning owing to the $\mathrm{PbI}_{2}$ vapor produced during the first growth step. Moreover, the high temperature growth process requires substrates that have high melting point $\left(>350^{\circ} \mathrm{C}\right)$, which are not suitable for flexible substrates with low melting point. Therefore, the need for developing other alternative routes to produce high quality perovskite platelets without lead halide vapour during the process on diverse substrates, especially on flexible substrates remains a challenge.

Previously, we introduce a two-steps method to produce high quality 2D perovskite platelets on $\mathrm{SiO}_{2} / \mathrm{Si}$ substrate [13]. The highest growth temperature during the process was around $180{ }^{\circ} \mathrm{C}$. In this manuscript, we carefully control the growth temperature to below $100{ }^{\circ} \mathrm{C}$, therefore high quality 2D perovskite platelets can be obtained on random substrates, especially on transparent, flexible and lower melting point substrates. Our method is applicable to any substrate as long as its melting point is higher than $100^{\circ} \mathrm{C}$. Moreover, photodetectors based on the as-produced 2D perovskite platelets were fabricated. The devices exhibit excellent photoresponse performance, including a high photoresponsivity of $8.3 \mathrm{AW}^{-1}$, a high on/off ratio of $\sim 10^{3}$, and a small rise and decay time of 30 and $50 \mathrm{~ms}$, respectively. Considering the feasibility of preparing 2D perovskite platelets with different thickness on diverse substrates, especially on transparent, flexible and lower melting point substrates, the results in this paper would greatly extend the device applications of $2 \mathrm{D}$ perovskite.

\section{Materials and Methods}

The $2 \mathrm{D} \mathrm{CH}_{3} \mathrm{NH}_{3} \mathrm{PbI}_{3}$ platelets were prepared by two steps. Firstly, $0.2 \mathrm{mg} \mathrm{PbI}_{2}$ powder was dissolved in $1 \mathrm{~mL}$ distilled water and heated at $100{ }^{\circ} \mathrm{C}$ for $1 \mathrm{~h}$ to get oversaturated $\mathrm{PbI}_{2}$ solution. After this, the hot $\mathrm{PbI}_{2}$ solution (around $100{ }^{\circ} \mathrm{C}$ ) was dropped on the aimed heating substrates, including $\mathrm{SiO}_{2} / \mathrm{Si}$, $\mathrm{Si}$, mica, glass and PDMS. During this process, the $\mathrm{PbI}_{2}$ oversaturated solution would nucleate and form the $2 \mathrm{D} \mathrm{PbI}_{2}$ platelets on the corresponding substrates. Secondly, $\mathrm{CH}_{3} \mathrm{NH}_{3} \mathrm{I}$ powder was put into the center of the furnace and the above obtained $2 \mathrm{D} \mathrm{PbI}_{2}$ platelets were placed 10-15 cm downstream from the $\mathrm{CH}_{3} \mathrm{NH}_{3}$ I powder in a CVD system (Hefei, Anhui, China) to convert to $\mathrm{CH}_{3} \mathrm{NH}_{3} \mathrm{PbI}_{3}$ perovskite. After that, $500 \mathrm{sccm}$ Ar was introduced into the CVD system for $30 \mathrm{~min}$ to clear the air in the quartz tube. The Ar flow rate was then kept at $30 \mathrm{sccm}$ to maintain the system pressure to be lower than 1 Torr. Afterword, the furnace was heated to $100{ }^{\circ} \mathrm{C}$ under a heating rate of $2.5^{\circ} \mathrm{C} / \mathrm{min}$ and kept at $100{ }^{\circ} \mathrm{C}$ for 5-30 min. Finally, we stopped heating and opened the furnace quickly. During this process, the $\mathrm{CH}_{3} \mathrm{NH}_{3} \mathrm{I}$ molecules would insert into the $2 \mathrm{D} \mathrm{PbI}_{2}$ platelets to convert them into $2 \mathrm{D} \mathrm{CH} \mathrm{NH}_{3} \mathrm{PbI}_{3}$ perovskite platelets. Moreover, the heating rate should not be very quick as higher heating rate usually induces temperature overshoot $\left(>100^{\circ} \mathrm{C}\right)$, and there would be more $\mathrm{CH}_{3} \mathrm{NH}_{3} \mathrm{I}$ molecules inserted into the $\mathrm{PbI}_{2}$ platelets than as needed.

The photodetectors were fabricated by picking up a single organic ribbon by a mechanical probe and placed over the 2D perovskite platelet as an organic ribbon mask. After this, $30 \mathrm{~nm} \mathrm{Au}$ was deposited on the 2D perovskite platelet by thermal evaporation. Finally, the organic ribbon mask was peeled off by a mechanical probe to form the source and drain electrodes over the 2D perovskite platelet. The morphology and structure of the as-grown 2D perovskite platelets were characterized by field-emission scanning electron microscopy (FESEM, Model S-4800, Hitachi, Tokyo, 
Japan), optical microscopy (Olympus BX51, Shinjuku, Tokyo, Japan), atomic force microscopy (AFM, Bruker, Dimension Icon SPM, Billerica, MA, USA) in the tapping model and X-ray diffraction (XRD, Bruker D8 advanced diffractometer, $\mathrm{Cu}-\mathrm{K} \alpha$ radiation $(\lambda=1.54050 \AA)$, Billerica, Massachusetts, United States ) scanned from 10 to $60^{\circ}$ with a step of $0.02^{\circ}$. Chemical composition and crystal orientation of the 2D perovskite platelets were analyzed by X-ray photoelectron spectroscopy (XPS) and transmission electron microscope (TEM, FEI, Hillsboro, OR, USA, Tecnai G2 F20). Photoluminescence (PL) spectrum and mapping measurements were performed using a confocal microscope system (WITec, Ulm, Germany, alpha 300R) with $532 \mathrm{~nm}$ wavelength laser to excite the samples. The photoresponse properties of the photodetectors were characterized using the probe station (Cascade, Kingsey Falls, QC, Canada, M150) and a semiconductor property analyzer (Keithley, Cleveland, OH, USA, 4200) under $405 \mathrm{~nm}$ laser excitation.

\section{Results}

Figure 1 shows the morphology of $2 \mathrm{D} \mathrm{PbI}_{2}$ and $\mathrm{CH}_{3} \mathrm{NH}_{3} \mathrm{PbI}_{3}$ perovskite platelets characterized by optical microscopy, SEM and AFM. Figure 1a-d show the optical microscopy images of hexagonal and triangular $2 \mathrm{D} \mathrm{PbI}_{2}$ on $\mathrm{Si}$, mica, glass and flexible PDMS substrates, respectively. We can observe that the surfaces of all the $2 \mathrm{D} \mathrm{PbI}_{2}$ platelets are smooth and uniform, no matter the substrate is rigid ( $\mathrm{Si}$, mica and glass)/flexible (PDMS) or smooth (Si and mica)/rough (PDMS and glass), which indicates that the toughness and roughness of the substrates do not play a key role during the $\mathrm{PbI}_{2}$ single crystal growth process. Figure 1e-h show the optical microscope images of $2 \mathrm{D}$ perovskite platelets on $\mathrm{Si}$, mica, glass and PDMS substrates, respectively, which were converted from the single crystal $\mathrm{PbI}_{2}$ by inserting $\mathrm{CH}_{3} \mathrm{NH}_{3} \mathrm{I}$ molecules into them. After the conversion, the surfaces of perovskite platelets were found to be non-uniform and relatively rough compared to their counterparts before the conversion. The surface morphology change is induced by insertion of $\mathrm{CH}_{3} \mathrm{NH}_{3} \mathrm{I}$ molecules into the lattice of single crystal $\mathrm{PbI}_{2}$. Notably, we can obtain $\mathrm{CH}_{3} \mathrm{NH}_{3} \mathrm{PbI}_{3}$ perovskite on almost all kinds of substrates as long as its melting point is higher than $100{ }^{\circ} \mathrm{C}$, which is the highest temperature during the whole process. Figure 1i-p show the optical and SEM images of perovskites with different thickness from hundreds of nanometers to a single-unit-cell thick $(2 \mathrm{~nm})$ on $\mathrm{SiO}_{2} / \mathrm{Si}$ substrate. Clearly, the surface of the 2D perovskites is more rough for the hundreds-nanometer-thick (Figure 1i) and the single-unit-cell-thick samples (Figure 11), but the ten-nanometer-thick sample exhibits a much smoother surface (Figure 1k). AFM was used to explore the morphology and thickness of the 2D perovskite platelets, as shown in Figure 1q-t. Samples with thickness of $450 \mathrm{~nm}, 175 \mathrm{~nm}, 150 \mathrm{~nm}$ and $60 \mathrm{~nm}$ were measured. AFM morphology indicates a surface roughness of $24 \mathrm{~nm}, 22 \mathrm{~nm}, 18 \mathrm{~nm}$ and $13 \mathrm{~nm}$, corresponding to $450 \mathrm{~nm}$, $175 \mathrm{~nm}, 150 \mathrm{~nm}$ and $60 \mathrm{~nm}$ samples, respectively. From Figure 1s,t, we can even find small particles on the surface of thinner samples, this proves again that the $\mathrm{CH}_{3} \mathrm{NH}_{3} \mathrm{I}$ molecules insert into the $\mathrm{PbI}_{2}$ crystal and result in the surface morphology change.

Figure 2a shows the XRD patterns of the $2 \mathrm{D} \mathrm{PbI}_{2}$ and the corresponding $\mathrm{CH}_{3} \mathrm{NH}_{3} \mathrm{PbI}_{3}$ perovskite platelets on glass substrates with a thickness of $10 \mathrm{~nm}$. The strong (110) and (220) diffraction peaks with $2 \theta$ located at $13.9^{\circ}$ and $28.17^{\circ}$ indicate that the obtained $\mathrm{CH}_{3} \mathrm{NH}_{3} \mathrm{PbI}_{3}$ perovskite is of tetragonal crystalline structure. Moreover, comparing the diffraction peaks of $\mathrm{PbI}_{2}$ and $\mathrm{CH}_{3} \mathrm{NH}_{3} \mathrm{PbI}_{3}$ perovskite, we can observe that the (001), (002), (003), (004) diffraction peaks of $\mathrm{PbI}_{2}$ disappeared after the conversion process, indicating that the $\mathrm{PbI}_{2}$ was completely converted to $\mathrm{CH}_{3} \mathrm{NH}_{3} \mathrm{PbI}_{3}$ perovskite crystals. Note that the normally observed (112), (211), (310) and (224) diffraction peaks in perovskite synthesized via solution method are not observed in our samples, attesting the fine crystal orientation of the converted $\mathrm{CH}_{3} \mathrm{NH}_{3} \mathrm{PbI}_{3}$ perovskite [30]. In order to characterize the optical properties of the converted perovskite, PL spectra were collected under $532 \mathrm{~nm}$ laser excitation at room temperature, as shown in Figure 2b and Figure S1a,b. Samples with different thickness that varies from $63 \mathrm{~nm}$ to single unit cell thick ( $2 \mathrm{~nm}$ ) were marked by $\mathrm{p} 1$ to $\mathrm{p} 6$. The PL peak shifts towards shorter wavelength from 770 to $720 \mathrm{~nm}$ as the thickness of the perovskite decreases from $100 \mathrm{~nm}$ to single unit cell (2 $\mathrm{nm})$, which is consistent with the previous report [13] and can be ascribed to the lattice expansion, 
namely, the structure relaxation of the in-plane crystal lattice could increase the optical band gap [31]. Moreover, we found that the PL intensity reduces dramatically by over 30 times as the film thickness decreases from $63 \mathrm{~nm}$ (marked by p1 in Figure 2b and Figure S1a,b) to single unit cell (2 nm, marked by $\mathrm{p} 6$ as shown in the upper left inset in Figure 2b and Figure S1a,b), owing to more excited charge carriers in the thicker perovskite under the laser irradiation. While for thinner perovskite, the carrier density is much less than that of thicker one, resulting in lower PL quantum yield efficiency. To further elucidate the relationship between the perovskite thickness and the corresponding PL intensity and peak position, PL mapping measurements were performed on 2D perovskite platelets, as shown in Figure 2c-f. When the perovskite thickness is larger than $100 \mathrm{~nm}$, the boundary PL intensity is much higher than that in the central part (Figure 2c). In addition, this phenomenon still can be observed when the thickness decreases to $20 \mathrm{~nm}$ (inner triangular perovskite sheet in Figure 2d), although the intensity contrast is lower than that of the thicker ones. However, as the thickness decreases to thinner than $10 \mathrm{~nm}$, the PL intensity is uniform over the whole crystal and no clear intensity contrast can be observed (inner triangular perovskite sheet in Figure 2e). While converting $\mathrm{PbI}_{2}$ to perovskite by inserting $\mathrm{CH}_{3} \mathrm{NH}_{3} \mathrm{I}$ molecules into it, the crystal boundary region of $\mathrm{PbI}_{2}$ is much easier to react with $\mathrm{CH}_{3} \mathrm{NH}_{3} \mathrm{I}$ molecules due to the large exposed edges than the central part during the conversion process, whereas, for the central part, the reaction first occurs at the surface and then towards inside the material. For thicker $\mathrm{PbI}_{2}$, the $\mathrm{CH}_{3} \mathrm{NH}_{3} \mathrm{I}$ molecules cannot insert into it through the surface easily, and consequently there are not enough $\mathrm{CH}_{3} \mathrm{NH}_{3} \mathrm{I}$ molecules involved into the reaction, resulting in the lower PL intensity from the central part than that from the boundary part. As the $\mathrm{PbI}_{2}$ thickness decreases, the insertion of $\mathrm{CH}_{3} \mathrm{NH}_{3} \mathrm{I}$ molecules becomes much easier though its surface, and thus the PL intensity difference between the central part and the boundary part is gradually reduced. As the thickness further decreases to $10 \mathrm{~nm}$, sufficient number of $\mathrm{CH}_{3} \mathrm{NH}_{3} \mathrm{I}$ molecules can insert into $\mathrm{PbI}_{2}$ though its surface, thereby there is no obvious intensity difference between the central part and the boundary part (Figure 2e). Figure $2 \mathrm{f}$ proved again that the boundary PL intensity is much higher than the central part and the thicker perovskite have higher PL intensity as clarified in Figure $2 b$. To more intuitively demonstrate the above effect, $\mathrm{PbI}_{2}$ platelet is converted to $\mathrm{CH}_{3} \mathrm{NH}_{3} \mathrm{PbI}_{3}$ perovskite without supplying sufficient $\mathrm{CH}_{3} \mathrm{NH}_{3} \mathrm{I}$ molecules, and the resultant $\mathrm{PL}$ spectrum of the $\mathrm{CH}_{3} \mathrm{NH}_{3} \mathrm{PbI}_{3}$ perovskite is shown in Figure S2a,b, from which we can observe that the boundary exhibits higher PL intensity, and the intensity in the central part is very low, attesting the above analysis.

Figure 3a displays the TEM image of a hexagonal 2D perovskite platelet with a thickness of $10 \mathrm{~nm}$. The corresponding high resolution TEM (HRTEM) image in Figure $3 b$ shows clear lattice fringes with (200) and $(0 \overline{2} 2)$ planes, further revealing the single crystalline structure of the converted perovskite platelet [13]. In order to understand the elemental arrangement of $\mathrm{Pb}$ in the perovskite platelets, scanning photoelectron microscopy (SPEM) was applied to obtain the XPS mapping image, as shown in Figure 3c. From the $\mathrm{Pb}$ mapping results, we can observe that the $\mathrm{Pb}$ arranged uniformly in the crystal after inserting the $\mathrm{CH}_{3} \mathrm{NH}_{3} \mathrm{I}$ molecules into the crystal. Moreover, single XPS spectra of $\mathrm{Pb}, \mathrm{I}, \mathrm{C}$ and $\mathrm{N}$ elements in the $\mathrm{CH}_{3} \mathrm{NH}_{3} \mathrm{PbI}_{3}$ perovskite were also acquired and shown in Figure $3 \mathrm{~d}-\mathrm{g}$, respectively. The prominent $\mathrm{C}_{1 \mathrm{~s}}$ peak located at $285.3 \mathrm{eV}$ corresponds to the carbon atoms in $\mathrm{CH}_{3} \mathrm{NH}_{3} \mathrm{PbI}_{3}$ crystal, and a small amount of amorphous carbon located at $284.2 \mathrm{eV}$ can also be seen, which may be due to the Si substrate contamination (Figure $3 \mathrm{f}$ ). The $\mathrm{I}_{4 \mathrm{~d}}, \mathrm{~Pb}_{4 \mathrm{f}}$ and $\mathrm{N}_{1 \mathrm{~s}}$ peaks are located at $(49.8 \mathrm{eV}, 51.4 \mathrm{eV})$, $(138.8 \mathrm{eV}, 144.3 \mathrm{eV})$ and $(399 \mathrm{eV}, 401.8 \mathrm{eV})$ respectively, which are in good agreement with previous reports [32-34]. 



Figure 1. (a-d) Optical microscopy images of the hexagonal and triangular $2 \mathrm{D} \mathrm{PbI}_{2}$ platelets on $\mathrm{Si}$, mica, glass and PDMS substrates, respectively; (e-h) Optical microscopy images of the hexagonal and triangular $2 \mathrm{D} \mathrm{CH} \mathrm{CH}_{3} \mathrm{PbI}_{3}$ perovskite on $\mathrm{Si}$, mica, glass and PDMS substrates, respectively; $(\mathbf{i}-\mathbf{l})$ and $(\mathbf{m}-\mathbf{p})$ Optical microscopy and SEM images of $2 \mathrm{D} \mathrm{CH}_{3} \mathrm{NH}_{3} \mathrm{PbI}_{3}$ perovskite with different thicknesses from hundreds of nanometers to single unit cell thick $(2 \mathrm{~nm})$ on $\mathrm{SiO}_{2} / \mathrm{Si}$ substrate; $(\mathbf{q}-\mathbf{t})$ AFM topography images of $2 \mathrm{D} \mathrm{CH}_{3} \mathrm{NH}_{3} \mathrm{PbI}_{3}$ perovskite platelets with different thicknesses from $450 \mathrm{~nm}$ to $60 \mathrm{~nm}$, respectively. All the scale bars are $10 \mu \mathrm{m}$. 

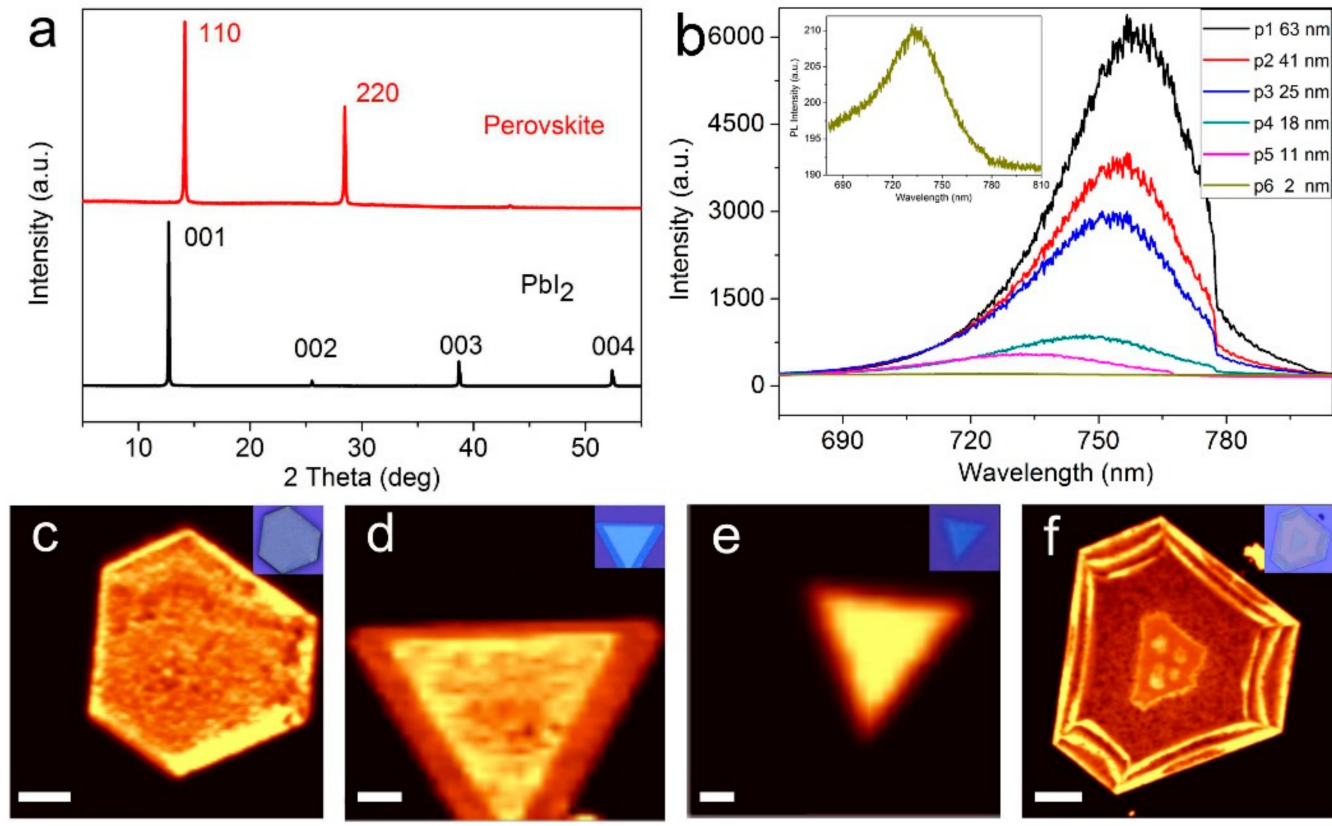

Figure 2. (a) $\mathrm{XRD}$ patterns of $\mathrm{PbI}_{2}$ platelets and corresponding converted $2 \mathrm{D} \mathrm{CH}_{3} \mathrm{NH}_{3} \mathrm{PbI}_{3}$ platelets. The thickness of $\mathrm{CH}_{3} \mathrm{NH}_{3} \mathrm{PbI}_{3}$ platelets is $10 \mathrm{~nm}$; (b) PL spectra of perovskite platelets with different thicknesses. The upper left inset shows the PL spectra of $2 \mathrm{~nm}$ perovskite; (c-f) PL mapping images of $2 \mathrm{D} \mathrm{CH}_{3} \mathrm{NH}_{3} \mathrm{PbI}_{3}$ platelets with different thicknesses. As shown in $(\mathbf{c}, \mathbf{d})$, when the platelet is thicker than $10 \mathrm{~nm}$, the PL intensities of the central part are lower than that of the boundary part. The upright insets in (c-f) show the corresponding optical microscopy images of $2 \mathrm{D} \mathrm{CH}_{3} \mathrm{NH}_{3} \mathrm{PbI}_{3}$ platelets. The scale bars are $4,7,1$ and $10 \mu \mathrm{m}$, respectively.
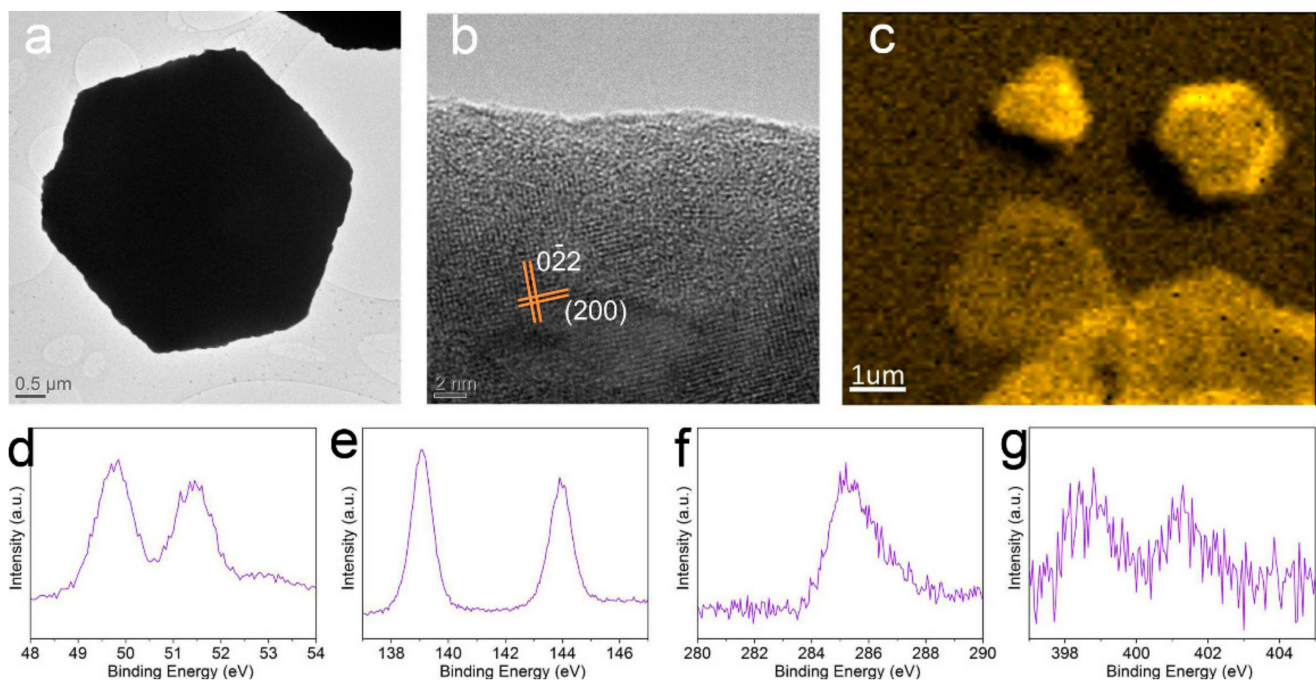

Figure 3. (a) TEM image of a $2 \mathrm{D} \mathrm{CH}_{3} \mathrm{NH}_{3} \mathrm{PbI}_{3}$ platelet; (b) High-resolution TEM image of the 2D $\mathrm{CH}_{3} \mathrm{NH}_{3} \mathrm{PbI}_{3}$ platelet; (c) XPS mapping images of $\mathrm{Pb}$ element in $2 \mathrm{D} \mathrm{CH}_{3} \mathrm{NH}_{3} \mathrm{PbI}_{3}$ platelets acquired with SPEM; (d-g) XPS spectra of Pb, I, C and N elements in $2 \mathrm{D} \mathrm{CH}_{3} \mathrm{NH}_{3} \mathrm{PbI}_{3}$ platelets, respectively.

\section{Discussion}

Controlled growth of 2D perovskite platelets on different substrates enables us to probe their intrinsic optoelectrical properties. As an example, perovskite platelets were explored as the semiconducting channel of FETs on $\mathrm{SiO}_{2} / \mathrm{Si}$ substrate with two gold electrodes as source/drain 
electrodes and $\mathrm{Si}$ as the back gate. Schematic and optical microscopy image of a $2 \mathrm{D} \mathrm{CH}_{3} \mathrm{NH}_{3} \mathrm{PbI}_{3}$ platelet phototransistor are shown in Figure 4a and Figure S3a. The results in Figure $4 \mathrm{~b}$ display a nearly zero dark current and linear $I-V$ curves under two different illumination powers with $405 \mathrm{~nm}$ laser excitation, indicating that the device has excellent photoresponse capability. The linear $I-V$ curves indicate the Ohmic contact between perovskite and gold source/drain electrodes. Figure $4 \mathrm{c}$ shows the device response to pulsed light at different optical pumping power, from which we can observe that the device can be effectively switched "ON" and "OFF" while the laser source is turned on and off. The amplitude of the electrical signal is modulated by different light powers. Also from Figure $4 \mathrm{c}$ we can calculate the photocurrent to dark current ratio of our devices and the value can reach up to three orders of magnitude. Figure $4 \mathrm{~d}$ shows the photoresponsivity and photocurrent as a function of the light power. It is found that both the photocurrent and photoresponsivity change nonlinearly with increasing the laser power. The photoresponsivity of our 2D perovskite based FET can reach up to $8.3 \mathrm{AW}^{-1}$ under a bias voltage of $1 \mathrm{~V}$, higher than the bulk perovskite film based devices $\left(3 \mathrm{AW}^{-1}\right)$ but lower than perovskite crystal $\left(40 \mathrm{AW}^{-1}\right)$ based ones with channel length reducing to $100 \mathrm{~nm}$ [15]. The response speed of our device is characterized by a rise time and a decay time of less than 30 and $50 \mathrm{~ms}$, respectively, demonstrating a much faster response than the bulk perovskite film based devices. In addition, time-dependent photocurrents at different source-drain voltages are shown in Figure $4 \mathrm{f}$ and Figure S3b. The photocurrent can be significantly increased by increasing the source-drain voltage. As the laser is turned on and off, the photocurrent changes periodically, indicating a very good operation repeatability. The above results prove that our $2 \mathrm{D}$ perovskite platelets show excellent photoelectric properties and hold a potential for broader optoelectronics application, especially for applications that need low temperature processing.
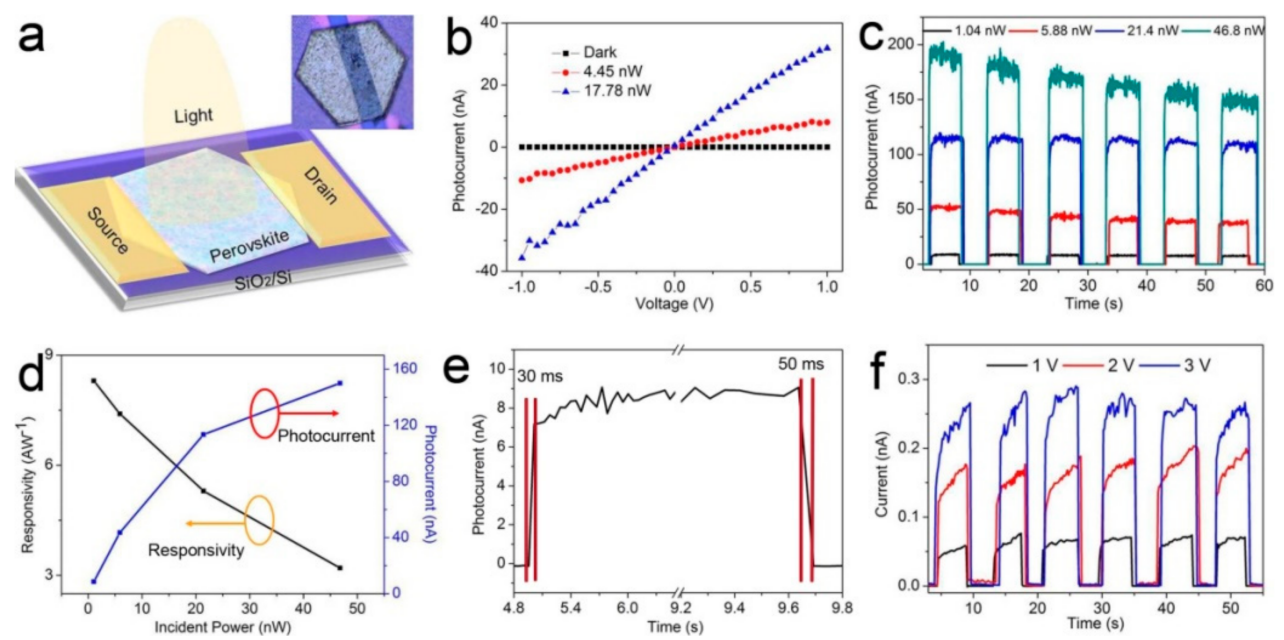

Figure 4. (a) Schematic of a $2 \mathrm{D} \mathrm{CH}_{3} \mathrm{NH}_{3} \mathrm{PbI}_{3}$ platelet phototransistor. The upright inset shows the optical microscopy image of the $2 \mathrm{D} \mathrm{CH}_{3} \mathrm{NH}_{3} \mathrm{PbI}_{3}$ platelet phototransistor; (b) $I-V$ curves of the $2 \mathrm{D}$ perovskite-based device in dark and under light irradiation with different power; (c) Time-dependent photocurrent of the $2 \mathrm{D} \mathrm{CH}_{3} \mathrm{NH}_{3} \mathrm{PbI}_{3}$ platelet with different incident power; (d) Dependence of photocurrent and photoresponsivity on incident light power; the blue and black dots correspond to original data; (e) Time photocurrent response excited at $405 \mathrm{~nm}$ laser. The rise time and the decay time are $30 \mathrm{~ms}$ and $50 \mathrm{~ms}$, respectively; (f) Time dependent photocurrent of the device based on the 2D $\mathrm{CH}_{3} \mathrm{NH}_{3} \mathrm{PbI}_{3}$ platelet during the laser switching on/off process under positive source-drain voltage, $\mathrm{V}_{\mathrm{sd}}$. $\mathrm{V}_{\mathrm{sd}}$ is from 1 to $3 \mathrm{~V}$.

\section{Conclusions}

In summary, high quality $2 \mathrm{D} \mathrm{CH} \mathrm{CH}_{3} \mathrm{PbI}_{3}$ perovskite platelets were prepared by a two-steps method. By utilizing this method, we can produce 2D perovskites platelets with different thicknesses 
from hundreds of nanometers to single unit cell $(2 \mathrm{~nm})$ on different substrates, as long as the melting point of the substrate is higher than $100{ }^{\circ} \mathrm{C}$. It was found that the PL characteristics of perovskite depends strongly on the platelet thickness, namely, thicker perovskite platelet has higher PL wavelength and stronger intensity, whereas, thinner perovskite exhibits opposite results. Moreover, photoelectric measurements confirm that our 2D perovskite platelets show excellent photoelectric properties. Phototransistors based on the $2 \mathrm{D}$ perovskite platelet exhibit a high photoresponsivity of $8.3 \mathrm{AW}^{-1}$, a high on/off ratio of $\sim 10^{3}$ with a small rise and a decay time of 30 and $50 \mathrm{~ms}$, respectively. Considering the feasibility of preparing 2D perovskite platelets with different thickness on diverse substrates, especially on transparent, flexible and lower melting point substrates, our method would greatly extend the device applications of 2D perovskite.

Supplementary Materials: The following are available online at http:/ /www.mdpi.com/2079-4991/8/8/591/s1, Figure S1: Optical microscopy and PL mapping images of $2 \mathrm{D} \mathrm{CH}_{3} \mathrm{NH}_{3} \mathrm{PbI}_{3}$ perovskite, Figure S2: Optical microscopy and PL mapping images of the converted $2 \mathrm{D} \mathrm{CH} \mathrm{NH}_{3} \mathrm{PbI}_{3}$ perovskite without supplying sufficient $\mathrm{CH}_{3} \mathrm{NH}_{3} \mathrm{I}$ molecules during the conversion process, Figure S3: supplementary photoelectrical performance of the $2 \mathrm{D} \mathrm{CH}_{3} \mathrm{NH}_{3} \mathrm{PbI}_{3}$ platelet phototransistor.

Author Contributions: Conceptualization, Y.X. and S.L.; Methodology, J.L. and J.Y.; Validation, Y.X.; Formal Analysis, Y.X., J.L., J.Y. and S.L.; Investigation, Y.X.; Resources, S.L.; Data Curation, Y.X.; Writing-Original Draft Preparation, Y.X., J.L., J.Y. and S.L.; Writing-Review \& Editing, S.L.; Visualization, Y.X. and S.L.; Supervision, S.L.; Project Administration, S.L.; Funding Acquisition, S.L.

Funding: This research was funded by the National Natural Science Foundation of China (No. 61604102, 51222208, 51290273), the National Key Research \& Development Program (No. 2016YFA0201902).

Acknowledgments: This work was performed in part at the Melbourne Centre for Nanofabrication (MCN) in the Victorian Node of the Australian National Fabrication Facility (ANFF).

Conflicts of Interest: The authors declare no conflict of interest. The founding sponsors had no role in the design of the study; in the collection, analyses, or interpretation of data; in the writing of the manuscript, and in the decision to publish the results.

\section{References}

1. Shi, S.; Li, Y.; Li, X.; Wang, H. Advancements in all-solid-state hybrid solar cells based on organometal halide perovskites. Mater. Horiz. 2015, 2, 378-405. [CrossRef]

2. Kojima, A.; Teshima, K.; Shirai, Y.; Miyasaka, T. Organometal Halide Perovskites as Visible-Light Sensitizers for Photovoltaic Cells. J. Am. Chem. Soc. 2009, 131, 6050-6051. [CrossRef] [PubMed]

3. Im, J.H.; Lee, C.R.; Lee, J.W.; Park, S.W.; Park, N.G. 6.5\% Efficient perovskite quantum-dot-sensitized solar cell. Nanoscale 2011, 3, 4088-4093. [CrossRef] [PubMed]

4. Kim, H.S.; Lee, C.R.; Im, J.H.; Lee, K.B.; Moehl, T.; Marchioro, A.; Moon, S.J.; Humphry-Baker, R.; Yum, J.H.; Moser, J.E.; et al. Lead Iodide Perovskite Sensitized All-Solid-State Submicron Thin Film Mesoscopic Solar Cell with Efficiency Exceeding 9\%. Sci. Rep. 2012, 2, 591. [CrossRef] [PubMed]

5. Lee, M.M.; Teuscher, J.; Miyasaka, T.; Murakami, T.N.; Snaith, H.J. Efficient Hybrid Solar Cells Based on Meso-Superstructured Organometal Halide Perovskites. Science 2012, 338, 643-647. [CrossRef] [PubMed]

6. Etgar, L.; Gao, P.; Xue, Z.; Peng, Q.; Chandiran, A.K.; Liu, B.; Nazeeruddin, M.K.; Grätzel, M. Mesoscopic $\mathrm{CH}_{3} \mathrm{NH}_{3} \mathrm{PbI}_{3} / \mathrm{TiO}_{2}$ Heterojunction Solar Cells. J. Am. Chem. Soc. 2012, 134, 17396-17399. [CrossRef] [PubMed]

7. Burschka, J.; Pellet, N.; Moon, S.J.; Humphry-Baker, R.; Gao, P.; Nazeeruddin, M.K.; Grätzel, M. Sequential deposition as a route to high-performance perovskite-sensitized solar cells. Nature 2013, 499, 316-319. [CrossRef] [PubMed]

8. Liu, M.; Johnston, M.B.; Snaith, H.J. Efficient planar heterojunction perovskite solar cells by vapour deposition. Nature 2013, 501, 395-398. [CrossRef] [PubMed]

9. Heo, J.H.; Im, S.H.; Noh, J.H.; Mandal, T.N.; Lim, C.-S.; Chang, J.A.; Lee, Y.H.; Kim, H.-J.; Sarkar, A.; Nazeeruddin, M.K.; et al. Efficient inorganic-organic hybrid heterojunction solar cells containing perovskite compound and polymeric hole conductors. Nat. Photonics 2013, 7, 486-491. [CrossRef]

10. Kamat, P.V. Organometal Halide Perovskites for Transformative Photovoltaics. J. Am. Chem. Soc. 2014, 136, 3713-3714. [CrossRef] [PubMed] 
11. Xing, G.C.; Mathews, N.; Sun, S.Y.; Lim, S.S.; Lam, Y.M.; Grätzel, M.; Mhaisalkar, S.; Sum, T.C. Long-Range Balanced Electron- and Hole-Transport Lengths in Organic-Inorganic $\mathrm{CH}_{3} \mathrm{NH}_{3} \mathrm{PbI}_{3}$. Science 2013, 342, 344-347. [CrossRef] [PubMed]

12. Stranks, S.D.; Eperon, G.E.; Grancini, G.; Menelaou, C.; Alcocer, M.J.P.; Leijtens, T.; Herz, L.M.; Petrozza, A.; Snaith, H.J. Electron-Hole Diffusion Lengths Exceeding 1 Micrometer in an Organometal Trihalide Perovskite Absorber. Science 2013, 342, 341-344. [CrossRef] [PubMed]

13. Liu, J.; Xue, Y.; Wang, Z.; Xu, Z.Q.; Zheng, C.; Weber, B.; Song, J.; Wang, Y.; Lu, Y.; Zhang, Y. Two-Dimensional $\mathrm{CH}_{3} \mathrm{NH}_{3} \mathrm{PbI}_{3}$ Perovskite: Synthesis and Optoelectronic Application. ACS Nano 2016, 10, 3536-3542. [CrossRef] [PubMed]

14. Hu, X.; Zhang, X.; Liang, L.; Bao, J.; Li, S.; Yang, W.; Xie, Y. High-Performance Flexible Broadband Photodetector Based on Organolead Halide Perovskite. Adv. Funct. Mater. 2014, 24, 7373-7380. [CrossRef]

15. Wang, G.; Li, D.; Cheng, H.C.; Li, Y.; Chen, C.Y.; Yin, A.; Zhao, Z.; Lin, Z.; Wu, H.; He, Q.; et al. Wafer-scale growth of large arrays of perovskite microplate crystals for functional electronics and optoelectronics. Sci. Adv. 2015, 1, e1500613. [CrossRef] [PubMed]

16. Wang, Y.; Zhang, Y.; Lu, Y.; Xu, W.; Mu, H.; Chen, C.; Qiao, H.; Song, J.; Li, S.; Sun, B.; et al. Hybrid Graphene-Perovskite Phototransistors with Ultrahigh Responsivity and Gain. Adv. Opt. Mater. 2015, 3, 1389. [CrossRef]

17. Li, J.; Bade, S.G.R.; Shan, X.; Yu, Z. Single-Layer Light-Emitting Diodes Using Organometal Halide Perovskite/Poly(ethylene oxide) Composite Thin Films. Adv. Mater. 2015, 27, 5196-5202. [CrossRef] [PubMed]

18. Tan, Z.K.; Moghaddam, R.S.; Lai, M.L.; Docampo, P.; Higler, R.; Deschler, F.; Price, M.; Sadhanala, A.; Pazos, L.M.; Credgington, D.; et al. Bright light-emitting diodes based on organometal halide perovskite. Nat. Nanotechnol. 2014, 9, 687-692. [CrossRef] [PubMed]

19. Qasim, K.; Wang, B.; Zhang, Y.; Li, P.; Wang, Y.; Li, S.; Lee, S.T.; Liao, L.S.; Lei, W.; Bao, Q. Solution-Processed Extremely Efficient Multicolor Perovskite Light-Emitting Diodes Utilizing Doped Electron Transport Layer. Adv. Funct. Mater. 2017, 27, 1606874. [CrossRef]

20. Wang, J.; Wang, N.; Jin, Y.; Si, J.; Tan, Z.K.; Du, H.; Cheng, L.; Dai, X.; Bai, S.; He, H.; et al. Interfacial Control Toward Efficient and Low-Voltage Perovskite Light-Emitting Diodes. Adv. Mater. 2015, 27, 2311-2316. [CrossRef] [PubMed]

21. Xing, G.; Mathews, N.; Lim, S.S.; Yantara, N.; Liu, X.; Sabba, D.; Gratzel, M.; Mhaisalkar, S.; Sum, T.C. Low-temperature solution-processed wavelength-tunable perovskites for lasing. Nat. Mater. 2014, 13, 476-480. [CrossRef] [PubMed]

22. Wang, Z.; Liu, J.; Xu, Z.Q.; Xue, Y.; Jiang, L.; Song, J.; Huang, F.; Wang, Y.; Zhong, Y.L.; Zhang, Y.; et al. Wavelength-tunable waveguides based on polycrystalline organic-inorganic perovskite microwires. Nanoscale 2016, 8, 6258-6264. [CrossRef] [PubMed]

23. Chin, X.Y.; Cortecchia, D.; Yin, J.; Bruno, A.; Soci, C. Lead iodide perovskite light-emitting field-effect transistor. Nat. Commun. 2015, 6, 7383. [CrossRef] [PubMed]

24. Ha, S.T.; Shen, C.; Zhang, J.; Xiong, Q. Laser cooling of organic-inorganic lead halide perovskites. Nat. Photonics 2016, 10, 115-121. [CrossRef]

25. Zhang, Q.; Ha, S.T.; Liu, X.; Sum, T.C.; Xiong, Q. Room-Temperature Near-Infrared High-Q Perovskite Whispering-Gallery Planar Nanolasers. Nano Lett. 2014, 14, 5995-6001. [CrossRef] [PubMed]

26. Mitzi, D.B.; Prikas, M.T.; Chondroudis, K. Thin Film Deposition of Organic-Inorganic Hybrid Materials Using a Single Source Thermal Ablation Technique. Chem. Mater. 1999, 11, 542-544. [CrossRef]

27. Zhang, Y.; Wang, Y.; Xu, Z.Q.; Liu, J.; Song, J.; Xue, Y.; Wang, Z.; Zheng, J.; Jiang, L.; Zheng, C.; et al. Reversible Structural Swell-Shrink and Recoverable Optical Properties in Hybrid Inorganic-Organic Perovskite. ACS Nano 2016, 10, 7031-7038. [CrossRef] [PubMed]

28. Zhang, Y.; Liu, J.; Wang, Z.; Xue, Y.; Ou, Q.; Polavarapu, L.; Zheng, J.; Qi, X.; Bao, Q. Synthesis, properties, and optical applications of low-dimensional perovskites. Chem. Commun. 2016, 53, 13637-13655. [CrossRef] [PubMed]

29. Ha, S.T.; Liu, X.; Zhang, Q.; Giovanni, D.; Sum, T.C.; Xiong, Q. Synthesis of Organic-Inorganic Lead Halide Perovskite Nanoplatelets: Towards High-Performance Perovskite Solar Cells and Optoelectronic Devices. Adv. Opt. Mater. 2014, 2, 838-844. [CrossRef] 
30. Noh, J.H.; Im, S.H.; Heo, J.H.; Mandal, T.N.; Seok, S.I. Chemical Management for Colorful, Efficient, and Stable Inorganic-Organic Hybrid Nanostructured Solar Cells. Nano Lett. 2013, 13, 1764-1769. [CrossRef] [PubMed]

31. Dou, L.; Wong, A.B.; Yu, Y.; Lai, M.; Kornienko, N.; Eaton, S.W.; Fu, A.; Bischak, C.G.; Ma, J.; Ding, T.; et al. Atomically thin two-dimensional organic-inorganic hybrid Perovskites. Science 2015, 349, 1518-1521. [CrossRef] [PubMed]

32. Li, Y.; Xu, X.; Wang, C.; Wang, C.; Xie, F.; Yang, J.; Gao, Y. Degradation by Exposure of Coevaporated $\mathrm{CH}_{3} \mathrm{NH}_{3} \mathrm{PbI}_{3}$ Thin Films. J. Phys. Chem. C 2015, 119, 23996-24002. [CrossRef]

33. Wang, C.; Wang, C.; Liu, X.; Kauppi, J.; Shao, Y.; Xiao, Z.; Bi, C.; Huang, J.; Gao, Y. Electronic structure evolution of fullerene on $\mathrm{CH}_{3} \mathrm{NH}_{3} \mathrm{PbI}_{3}$. Appl. Phys. Lett. 2015, 106, 111603. [CrossRef]

34. Quan, L.N.; Yuan, M.; Comin, R.; Voznyy, O.; Beauregard, E.M.; Hoogland, S.; Buin, A.; Kirmani, A.R.; Zhao, K.; Amassian, A.; et al. Ligand-Stabilized Reduced-Dimensionality Perovskites. J. Am. Chem. Soc. 2016, 138, 2649-2655. [CrossRef] [PubMed]

(c) 2018 by the authors. Licensee MDPI, Basel, Switzerland. This article is an open access article distributed under the terms and conditions of the Creative Commons Attribution (CC BY) license (http:// creativecommons.org/licenses/by/4.0/). 